\title{
Eogenetic karst, glacioeustatic cave pools and anchialine environments on Mallorca Island: a discussion of coastal speleogenesis
}

Angel Ginés ${ }^{1}$ and Joaquín Ginés ${ }^{2}$

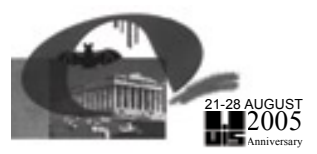

Paper presented during the 14th International Congress of Speleology, Kalamos (Greece) 21-28 August 2005.

\section{Abstract:}

Ginés A. and Ginés J. 2007. Eogenetic karst, glacioeustatic cave pools and anchialine environments on Mallorca Island: a discussion of coastal speleogenesis. International Journal of Speleology, 36 (2), 57-67. Bologna (Italy). ISSN 0392-6672.

Coastal karst is characterized by special geomorphologic and hydrodynamic conditions as well as by peculiar sedimentary, geochemical, and biospeleological environments. Generally, the more distinctive karstic features produced near the coastline are strongly influenced by sea-level changes, which generate a broad set of interactions between littoral processes and karst development. The glacioeustatic rises and falls of sea level affected the littoral karst in different ways, namely: vertical and horizontal shifts in the shoreline position, changes in elevation of the local water table, and vertical displacements of the halocline.

Most eogenetic karsts have been subjected over long time spans to repeated changes of a variety of vertically-zoned geochemical environments: vadose, phreatic meteoric-water, brackish mixing-waters and even marine water. Many coastal caves appear to be passively drowned by Holocene sea-level rise, and to contain glacioeustatic pools of varied size where the current water table intersects formerly air-filled chambers or passages. These coastal phreatic waters are controlled by sea level and fluctuate with tides. Significantly, features such as phreatic speleothems that are able to record ancient sea levels occur closely associated to the surface of the pools. The cave pools are brackish or even marine anchialine environments that contain remarkable communities of troglobitic stygofauna.

All of these aspects can be studied in detail along the southern and eastern coast of Mallorca Island owing to the widespread outcrop of Upper Miocene calcarenites, in which the development of eogenetic karst features started approximately 6 Ma ago, at the end of Messinian times. Some outstanding coastal caves result and include the celebrated Coves del Drac (explored by E.A. Martel in 1896), the labyrinthine Cova des Pas de Vallgornera (more than $30 \mathrm{~km}$ in length) and the recently explored Cova de sa Gleda (whose submerged passages exceed $10 \mathrm{~km}$, as shown by scuba-diving surveys).

Careful observations and detailed mapping of caves in the Upper Miocene reef rocks of Mallorca permit a better understanding of the coastal speleogenetic processes involved in a typical eogenetic karst over time ranges greater than $1 \mathrm{Ma}$. The role played by recurrent glacioeustatic oscillations of sea level and the subsequent rises and falls of the water table are emphasized in our model. There are two associated mechanisms: the triggering of breakdown by the loss of buoyant support that follows each lowering of sea level (i.e., during glaciations or smaller cold events) and the later underwater solution of boulders and collapse debris (during high sea levels that correspond to interglacial events). Additionally, tidal fluctuations affecting groundwaters would enhance solutional enlargement of caves and vug-porosity connected to the sea, rather than conventional karstic flow through conduits that probably is not as important an agent in eogenetic speleogenesis.

Keywords: coastal caves, eogenetic karst, speleogenesis, freshwater-seawater mixing zone, anchialine fauna, Mallorca

Received 27 November 2006; Revised 8 January 2007; Accepted 11 April 2007

\section{INTRODUCTION: COASTAL KARST AND EOGENETIC KARST}

Coastal karst constitutes a wide and interdisciplinary field of research that concerns not only karstologists, cave explorers, geomorphologists and

1 Àrea d'Ecologia, Departament de Biologia, Universitat de les Illes Balears, Crtra. de Valldemossa, $\mathrm{km} \mathrm{7.5}$,

07122- Palma de Mallorca, Spain

E-mail: agines@educacio.caib.es

2 Departament de Ciències de la Terra, Universitat de les Illes

Balears, Crtra. de Valldemossa, $\mathrm{km} 7.5$,

07122- Palma de Mallorca, Spain bioespeleologists. Interest in coastal karst is spread over many different fields, such as: geochemistry of underground waters, Quaternary paleoclimates related to sea-level changes, carbonate diagenesis, ecological constraints on stygofauna, microbiology of halocline habitats, and development of porosity suitable for paleokarst oil reservoirs, among other specialized topics. This remarkable interdisciplinary variety leads to a blossoming of overlapping terminology that can cause some confusion.

This paper deals only with three specific topics: eogenetic karst, glacioeustatic cave-pools and anchialine environments. These are useful terms and 
apply to a wide range of coastal karst areas throughout the world.

The term eogenetic karst has been introduced recently by Vacher \& Mylroie (2002) on the basis of the term eogenetic stage used by Choquette \& Pray (1970) in their classification of postdepositional stages affecting carbonate porosity. Eogenetic karst was defined by Vacher \& Mylroie (2002) as: “...the land surface evolving on, and the pore system developing in, rocks undergoing eogenetic, meteoric diagenesis... [That is, the karst developed on] young limestones experiencing meteoric diagenesis in the vicinity of their deposition".

The term glacioeustatic cave pools was introduced by Ginés \& Ginés (1977) to describe the unusual aquatic environments found in many coastal caves of Mallorca; glacioeustatic cave pools are considered to result from "passive drowning" of preexisting caves by a rise of the water table due to glacioeustatic sea levelchanges. These were termed sea-level pools by Palmer et al. (1977) and Ginés et al. (1981a \& 1981b).

The term anchihaline was introduced by the carcinologist Holthuis (1973) in the oddly spelled form "anchialine" pools (sic), in reference to water in hollows near the coast that are influenced by the present sea level. However, regarding the traditional usage in ecology and natural sciences of similar terms (like halocline, halite, euryhaline, halophile, etc.), we think it should be preferable to use the alternative spelling anchihaline, as suggested by Sket (1996).
Unfortunately, many recent publications seem to have standardized the term anchialine, as accepted implicitly by Sket (2005) in his recently published definition: "Anchihaline (or anchialine) habitats are water bodies in hollows along the sea coasts where the influence of the sea may be felt and which are inhabited by some subterranean species... Such a habitat may contain seawater, but it primarily has layers of different brackish salinities". The ecological concept of anchialine habitats has been discussed and refined by Stock et al. (1986), Sket (1996, 2004 $\&$ 2005), and Iliffe (2003). An interesting earlier approach to some karstic anchialine habitats can be found in Riedl \& Ozretic (1969).

\section{THE MAJORCAN COASTAL KARSTS}

About $45 \%$ of the $626 \mathrm{~km}$ of shoreline on Mallorca Island, consists of well-karstified limestones (Balaguer, 2005). Coastal karst features are significant forms in the littoral landscape and include different types of caves and karst remnants, as well as widespread solutional microforms and biokarstic karren (Ginés, 2000b). In addition, the hydrogeology of much of Mallorca is strongly influenced by local patterns of interconnected porosity resulting from coastal karst development.

Many karst aquifers lie in direct hydrologic contact with the sea along the coastline of the island, both in mountain ranges, such as Serra de Tramuntana

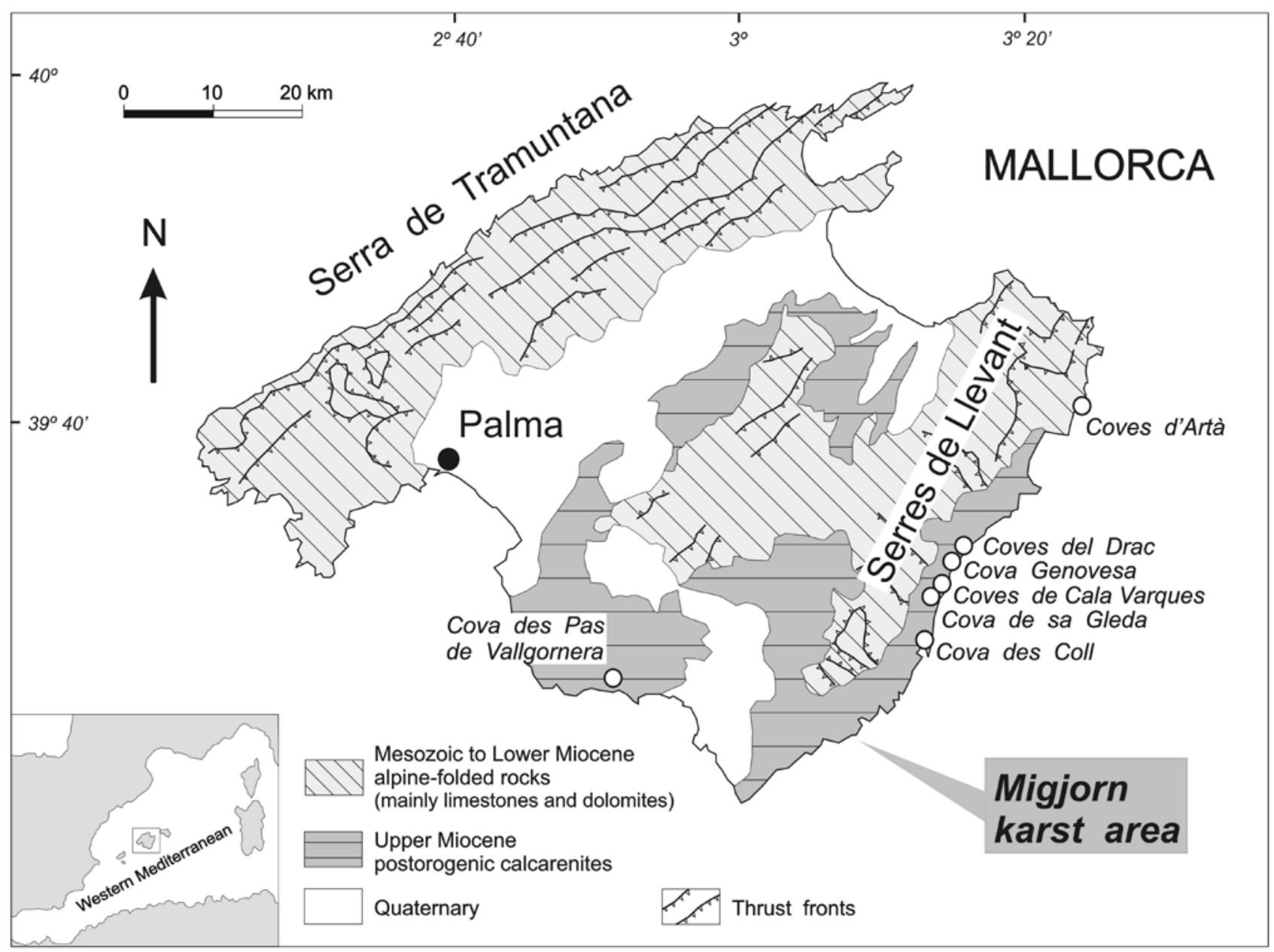

Fig. 1. Geological map of Mallorca showing the location of the caves cited in the text as well as the main karstic regions of the island. 
and Serres de Llevant, and in the post-orogenic (late Miocene) carbonate platform called Migjorn (Fig. 1). The mountainous karst is developed preferentially on limestones and dolomites of Mesozoic age (namely Rhaetian and Lower Jurassic); their occurrence along more than $175 \mathrm{~km}$ of coastline includes good examples of conventional telogenetic coastal karst (i.e., formed by exposure to karstification of the carbonates after deep burial). On the other hand, the karst developed along $120 \mathrm{~km}$ of the coast of Migjorn differs in typical examples of eogenetic karstification. This area is characterized by nearly flat-lying littoral plateaus made of very porous limestones and calcarenites of Upper Miocene age.

The Serra de Tramuntana is the highest and most important mountain range of Mallorca. It constitutes the whole northwestern side of the island and has a NE-SW alignment, its structure being characterized by a series of imbricate overthrust sheets (Gelabert et al., 1992) mainly composed of Mesozoic carbonate rocks. Impervious Upper Triassic marls (Keuper) at the base of the thrusts isolate and partition the karstic aquifers (basically Rhaetian dolomites and Lias limestones). In the slopes that delimit the 90-km-long NW shoreline of the island, widespread outcrops of Lower Jurassic (Lias) limestone produce magnificent cliffs as well as a variety of karst landforms and hydrogeologic conditions along their contact with the sea.

The Serres de Llevant is a mountain ridge in eastern Mallorca with less rugged topography than Serra de Tramuntana. Owing to alpine tectonics, both mountain ranges were built between Oligocene and Middle Miocene times (Gelabert, 1998) and have thrust sheets and related folds that constitute an integrated tectonic assemblage whose transport direction was preferentially towards the NW. In the Serres de Llevant, the main mountains are characterized by cliffs of Jurassic limestones and the more rounded forms correspond to crushed dolomites, marls, and thin-bedded limestones ranging from Jurassic to Cretaceous age. Although only part of this mountain range borders the shoreline, it contains numerous interesting examples of telogenetic coastal karst, including the celebrated show-cave known as Coves d'Artà.

The highly porous Upper Miocene limestones, which outcrop in Migjorn, constitute a post-orogenic platform that surrounds the "alpine structured" mountain ranges. This platform was formed by progradation of a Tortonian Reefal Complex composed of reef tracts and calcarenites overlying calcisiltites, which grades upward through mangroove facies and stromatolitic limestones into sand shoal oolites and calcarenites (Fornós et al., 2002a). The upper unit, called the Terminal Complex, is probably related to the Messinian crisis. These carbonates stretch across a relatively flat surface behind the coastal cliffs of the southern and eastern shores of the island that is interrupted only by incised dry valleys ending at littoral coves.

The thickness of these Upper Miocene carbonates which onlap the alpine folded basement is very irregular, showing mean values around $70 \mathrm{~m}$ and occasionally exceeding $120 \mathrm{~m}$. Because the Mesozoic basement consists mainly of karstifiable rocks (limestones and dolomites) with only minor marl intercalations, the karst area of Migjorn shares some resemblances with the complex island type from the Carbonate Island Karst Model, or CIKM, as postulated by Jenson et al. (2006); however, in this case the basement is not an impervious one and can even contribute to the recharge of the overlying Upper Miocene aquifers.

Regarding tectonics, Mallorca is part of the folded and thrusted belt resulting from the continental collision between the African and Iberian plates (Gelabert et al., 1992). Such a collision took place from the Upper Cretaceous to the Middle Miocene. In spite of the relevance of this orogenic event, the present geological architecture of the island is the result of a complex evolution involving extensional processes -occurred from the Neogene to the Quaternary- which are superimposed on the alpine compressive structure. The Upper Miocene carbonate platform of Migjorn was affected by such extensional tectonic activity and, in this way, the resulting coastal morphology was mostly controlled by recent normal faults which delimit the seaward border of the platform. Furthermore, this extensional post-orogenic activity is responsible for a marked tilting that affects the Migjorn plateau, being depressed towards the south and uplifted when reaching the $\mathrm{W}$ and $\mathrm{NE}$ ends of the karst area (Fornós et al., 2002b). The differential uplifting left the reefal Tortonian facies outcropping near the sea level at the southernmost part of the island whereas it appears higher than $40 \mathrm{~m}$ in the western and northeastern borders of Migjorn.

Because of the great extent of coastal karst in Mallorca and the remarkable contrast between the telogenetic karst of the Tramuntana-Llevant mountains and the eogenetic karst of the Migjorn platform, it is worthwhile to point out the particular characteristics of this area, especially with regard to speleogenesis. Our present knowledge is limited, but further studies and new explorations are in progress.

\section{CHARACTERISTICS AND SPELEOGENESIS OF A CLASSIC MAJORCAN CAVE: COVES DEL DRAC}

Coves del Drac (Fig. 2) is the most celebrated cavern in Mallorca and is visited each year by more than 800.000 tourists, and in this regard is one of the most important show-caves in the world. In spite of the great number of visitors and many publications about early explorations, the literature on the geology and ecology of the cave is scanty (Ginés \& Ginés, 1992).

Explorations began in the 19th century and were especially promoted by the Austrian Archduke Ludwig Salvator Habsburg-Lothringen, a learned maecenas and natural scientist who came to Mallorca in 1867. The Archduke sponsored both the first topographic survey of the cave, carried out by Friedrich Will in 1880, and the famous exploration undertaken by Edouard-Alfred Martel in 1896. The cave map produced by Martel, Pedro Bonet de los Herreros, Fernando Moragues, and Louis Armand during their historic exploration, showed nearly twice the length of the earlier map. It is noteworthy that the 1896 extensions 
were discovered by navigation of a glacioeustatic cave pool more than 150 metres long, named Llac Miramar, in honour of the Archduke's hospitality (he was the owner of the Miramar farmhouse), although it is now known as Martel's lake. In 1904, Émile G. Racovitza, accompanied by Fernando Moragues, found several troglobitic crustaceans in the waters of the glacioeustatic pools of the cave. These pools constitute a special geochemical and biotic environment that ecologists and biospeleologists classify today as a typical anchialine habitat. The description in 1905 of a new species of aquatic isopod, Typhlocirolana moraguesi Racovitza, is today considered a benchmark in the history of biospeleology, because this discovery focused the interest of Racovitza on the study of cave fauna (Ginés, 2005) and led to his highly recognized Essai sur les problèmes biospéologiques.

The entrance of the Coves del Drac is only 27 metres above the sea level. Its total length has been traditionally estimated to be roughly $2 \mathrm{~km}$, but the actual measured distance between the most widely separated survey stations is a little less than $1 \mathrm{~km}$. The plan-view map (Fig. 2) shows a wandering set of large passages, 30 to 50 metres in width, which are oriented randomly and are interrupted by huge volumes of columnar speleothems that partition the cave passages. The cave passages are in fact great breakdown chambers that are interconnected in a rather disordered pattern. The profiles and cross sections along the whole cave show more clearly the strong predominance of collapse processes, especially as vaults or domes clearly related to breakdown. On the other hand, even the smaller voids shown on the cave maps are neither solutional tubes nor spongework mazes. They are only minor room fragments resulting from partition of much wider collapse chambers and occur mainly where active

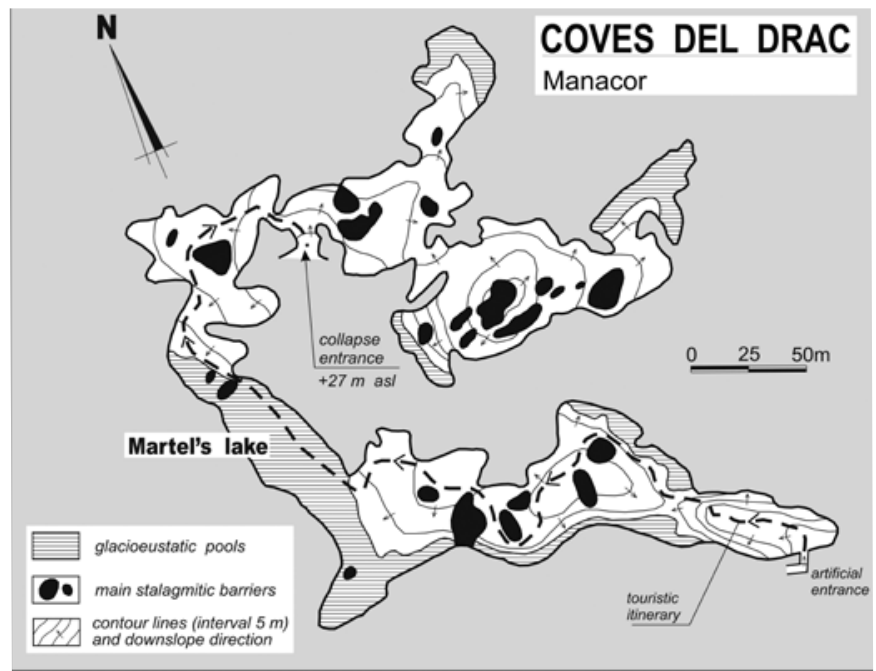

Fig. 2. Simplified cave survey of Coves del Drac. The cave is made up of several interconnected great collapse chambers that can be recognized on the map with the aid of the contour lines. The breakdown domes seem connected randomly without any directional control. The presence of glacioeustatic pools occupying the lower part of the chambers impede the access to the remnants of phreatic passages existing below the upward-growing breakdown domes. breakdown has connected isolated rooms, sometimes by way of the chaotic spaces between boulder heaps. In other places the collapse chambers are simply divided by the spectacular growth of speleothems, including stalagmites, columns and flowstone. The cave volume is quite remarkable, though, because nearly all the cave consists of an array of large and well-developed breakdown domes, which indicates a great amount of rock removal by speleogenesis.

It is not easy to explain how so huge a cavern has grown in the hydrogeologic context of such a highly porous and transmissive eogenetic karst aquifer. Both, ceiling and walls are completely lacking in diagnostic solutional features, and the floors are covered with piles of boulders and breakdown debris cemented over much of their area by flowstone. Most of the original solutional forms have presumably been destroyed by the upward growth of collapse domes, at the same time that speleothems contribute to hiding the older cave features. As a result, speleogenetic studies must rely exclusively on indirect evidence. The main evidence lies in the geochemical models of coastal karst waters, the geographic setting and the topographic patterns recognizable on detailed cave maps. Some of the discussions about the origin and evolution of Coves del Drac can be found in Ginés \& Ginés (1992) and Ginés (1995, 1997 and 2000a).

\section{THE UPPER MIOCENE EOGENETIC KARST OF MAJORCAN MIGJORN: CAVE ENVIRONMENTS AND RELATED HABITATS}

Majorcan post-orogenic reefs, which contain the eogenetic karst of Migjorn, were built during the Upper Miocene around the older alpine-structured mountain ranges and have become intensely karstified ever since the final Messinian times. Bioclastic calcarenites, shelly and oolitic limestones, and coral patches developed early solution features, some of which were even syngenetic (Fornós, 1998; RobledoArdila et al., 2004). Later karstification generated many kilometres of large cave passages during a time span of approximately $6 \mathrm{Ma}$, giving rise to outstanding examples of eogenetic, soft-rock karst. The proximity of the shoreline, together with the high rock porosity, produces a remarkably continuous phreatic zone whose water table is in hydrostatic equilibrium with sea level, with very low hydraulic gradients (less than $0.3 \%)$.

The most typical caves of the Late Miocene karst of Migjorn, such as the Coves del Drac already described, consist of one or more collapse chambers connected in an apparently random pattern (Ginés, 2000a). More than $90 \%$ of the caves explored and surveyed in the coastal karst of Migjorn are characterized by collapse chambers. The ceilings consist of well-developed vaults or domes that have nearly perfect rounded cross sections as the result of stress distribution around arched profiles. It is probable that this tendency would be related to the "soft-rock" behaviour of these relatively young limestones. Owing to recurrent collapse, the floors of the chambers are occupied by great unstable 
conical heaps of boulders and breakdown products that are partly hidden by speleothems. In plan view the more spacious and discrete chambers are generally elliptical or even circular, but crescent shapes are also common where the ceiling heights are lower and the vaulted chambers are more asymmetrical. Many submerged caves also consist of complex arrays of drowned collapse chambers, as is the case of Coves de Cala Varques (Gràcia et al., 2000) and Cova Genovesa (Gràcia et al., 2003: Fig. 8). Even the longest cave in Mallorca, the Cova des Pas de Vallgornera system, has several collapse chambers coexisting with more than $20 \mathrm{~km}$ of conduit passages (Merino et al., 2006) that are developed in the less porous lagoon facies of the reef. As explained before for Coves del Drac, breakdown processes on cave walls and ceilings enhance the further growth of each collapse unit (or breakout dome) and causes neighbouring collapse units to coalesce. In the same way, the slow upward migration of some breakout domes accounts for the origin of most of the natural entrances to the vast majority of caves in the Migjorn karst.

Solutional features are only visible in the walls of some chambers as well as in rather scarce passages of a small number of caves, probably because of destruction by breakdown. Furthermore, the accumulation of boulders on the floors of these collapse chambers hampers access to the bedrock and makes it difficult to find diagnostic evidence for dissolutional surfaces formed by moving water. When present, solutional features are usually observed near and below the current sea level (preferentially between +2 and $-15 \mathrm{~m}$ ), although there is also some minor evidence of phreatic dissolution located at higher elevation. Finally, neither the patterns observed on the cave maps nor the cave's morphology could be attributed anywhere to active underground streams related to vadose downcutting.

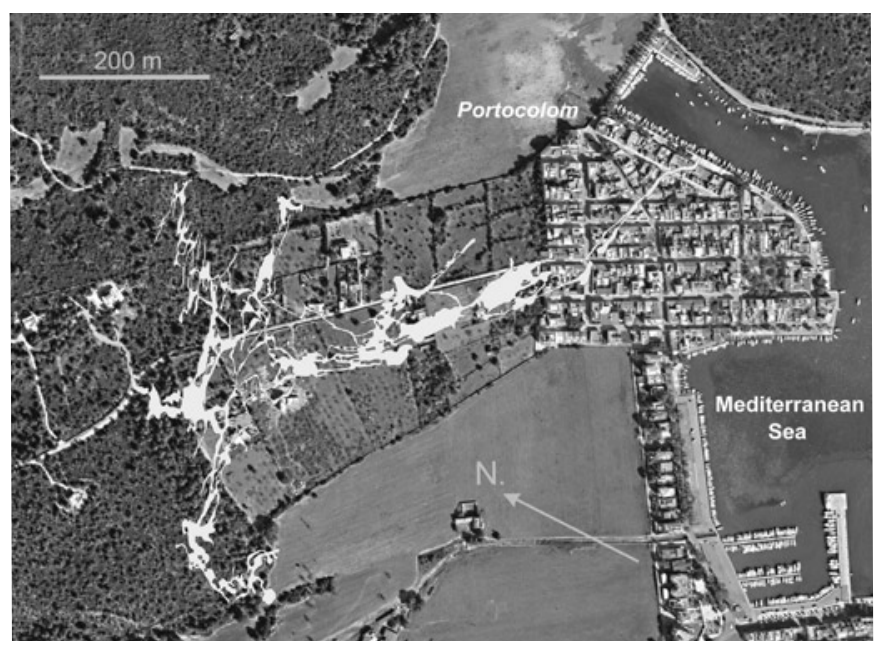

Fig. 3. Topographical cave survey of Cova des Coll plotted over an aerial photo from the Portocolom harbour area, after Gràcia et al. (2005). Note the presence of wide collapse chambers connected by underwater labyrinthine and rectilinear passages. Scuba-diver exploration has demonstrated that below the water table the cave follows a clear directional pattern mainly controlled by the joint system.
Throughout the karstified platform of Migjorn there are many caves occupied in their lower portions by brackish-water pools, whose surfaces rise and fall with tidal fluctuations of sea level. These flood levels constitute plainly the upper limit attained by the phreatic waters of the karstic aquifer in equilibrium with the sea, i.e., the regional water table. The tight sea-level and tidal control of these phreatic waters has been described by Rodés (1925) in his pioneering study of the glacioeustatic pools of Coves del Drac. The measured range for vertical fluctuations of the pools surface in the Majorcan caves is over $50 \mathrm{~cm}$, but presumably the observed oscillation amplitude depends mainly on the distance to the sea.

Glacioeustatic cave pools allow karstologists and biospeleologists to observe and sample coastal phreatic waters easily. Depending on the location of the cave and the depth of the cave pools it is possible to sample the water column from the oscillating surface to well below the halocline. Some authors have indicated that these kinds of freshwater-seawater mixing zones are among the most enigmatic diagenetic environments of coastal carbonates (e.g., Csoma et al., 2006). In this respect, an interesting phenomenon related to glacioeustatic cave pools is the presence of phreatic carbonate coatings on pool walls, which indicate the precise, both past and present, elevations of the water table (Ginés et al., 1981b; Vesica et al., 2000; Ginés 2000b; Fornós et al., 2002b \& Tuccimei et al., 2006).

All along the Majorcan coast, both eogenetic and telogenetic karsts can contain glacioeustatic cave pools and anchialine habitats. To delimit the term glacioeustatic pool more precisely, it is appropriate to specify that variations in their surface elevations can be controlled only by sea-level fluctuations. Otherwise, because cavers apply the term sump to any place in a cave passage when the water meets the roof, glacioeustatic cave pools could not be clearly differentiated from conventional sumps. Undoubtedly, glacioeustatic cave pools are among the most common, although not exclusive, characteristics of many eogenetic karsts. They can be expected in large coastal karsts as Yucatan (Thomas, 1999) or in soft-rock islands like Guam (Taboroši, 2004); but also they can be found in hard-rock karsts like Christmas Island (Grimes, 2001).

Recent scuba-diver exploration has demonstrated that our perception of the eogenetic karst of Migjorn was strongly biased by caver accessibility. The discovery of large extensions, particularly below the water table, have entirely changed the patterns of the cave maps by adding many kilometres of surveyed passages (Fig. 3). After these findings, the previously known caves, namely those accessible without scuba equipment, appear today as just the topmost part of an impressive system of coalescing collapse chambers whose "roots" remain drowned because of the latest (Holocene) glacioeustatic water-table rise. The impressive data collected by Gràcia et al. (1997, 2000, 2003, \& 2005) have shown much more evidence for underwater eogenetic speleogenesis (Fig. 3, 4 and 5) than that collected by conventional cavers 
in the non-drowned portions of the caves. In the same manner that are demonstrated by detailed reports containing dive explorations in the Mount Gambier karst (Grimes et al., 1999) and eastern Yucatan karst (Thomas, 1999; Smart et al., 2006), the Majorcan cave-diver surveys also stress the importance of long underwater passages and the findings of complex strings of submerged collapsing vaults (Fig. 6 and 7) below the water table. On the other hand, the very long and joint-controlled passages discovered quite recently in Cova des Coll (Fig. 3), Cova de sa Gleda and Cova des Pas de Vallgornera add more complexity to the modelling on coastal karst speleogenesis and call for detailed studies of the control of eogenetic karstification by stratigraphic heterogeneity as well as by differences in porosity between distinct lithofacies in the Upper Miocene reef complex of Mallorca (Pomar \& Ward, 1999).

\section{SOME REMARKS ABOUT EOGENETIC KARST}

The Upper Miocene karst of Migjorn was for many years explained on the basis of traditional karst processes. Only recently, the paper "Eogenetic karst from the perspective of an equivalent porous medium" by Vacher \& Mylroie (2002) has established a satisfactory frame for the understanding of the particular geomorphological features and hydrological behaviour observed in this typical soft rock eogenetic karst.

Post-depositional evolution and diagenesis occurring on such relatively young shallow-water carbonates, which simultaneously were karstified over approximately $6 \mathrm{Ma}$, produced significant porosity changes in a way quite different from conventional telogenetic karst. Redistribution of porosity, after the early lithification and later karst diagenesis, were accompanied by active speleogenetic processes that generated an impressive system of caves in the karst of Migjorn. As can be observed today, the preservation of large-scale reefal porosity after the initial stages of diagenesis, in the form of interconnecting pore systems, has not hindered (at least in the karst of Migjorn) the development of huge cavern-size voids, in spite of the easy transmission of water through numerous, well connected pores. For this reason, it must be assumed that only non-conventional karst processes can be responsible for the development of these large caves, especially taking into account high hydraulic conductivity and diffuse flow throughout the rock. At the same time it is necessary to explain the growth of localized highly porous zones into negotiable caves. It seems likely that enhanced solution of rock, near the shoreline, in the freshwater-seawater mixing zone (Back et al., 1984), in a similar way to the explanation proposed by Mylroie \& Carew (2000) for the "flank margin caves", as well as a long period of time (at least $1 \mathrm{Ma}$ ) could explain the origin of wide collapse-type caves like those observed in the Upper Miocene of Mallorca.

According to Vacher \& Mylroie (2002), "the double porosity of eogenetic karsts consists of small stringers,

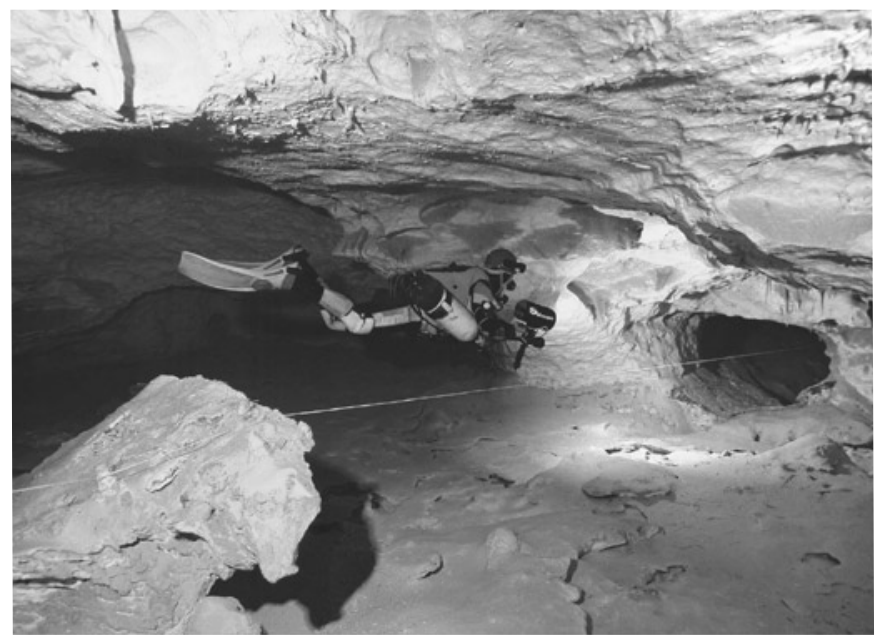

Fig. 4. Typical appearance of a phreatic passage in Cova de Cala Varques B. Solutional features are dominant but breakdown processes are also occasionally present. Note the fallen boulder in the foreground.

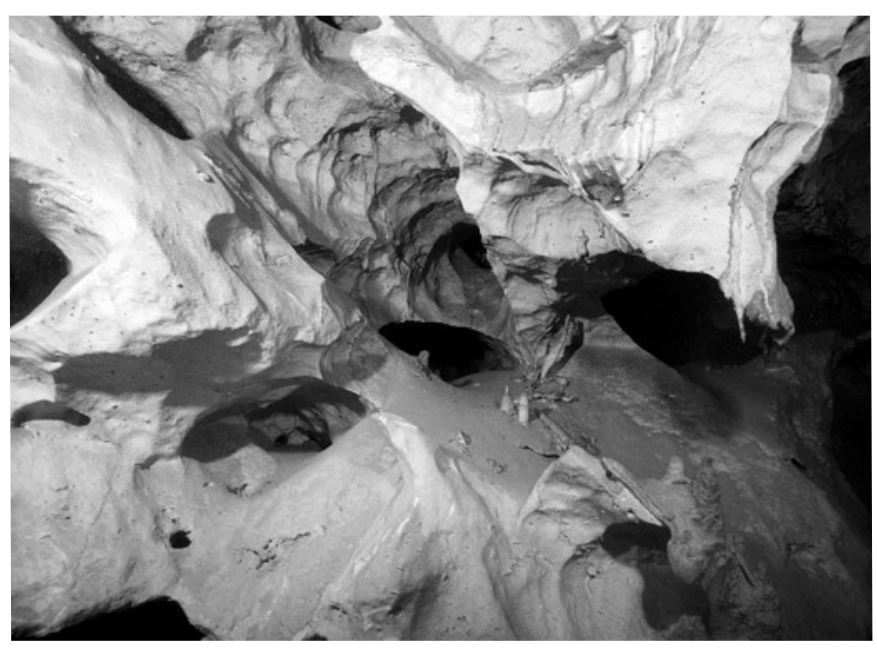

Fig. 5. Undulating corrosional forms and solution pockets on the walls of a phreatic passage from Cova Genovesa. Some underwater passages of this cave, preserving phreatic-corrosion forms, are a likely model that could explain the former stages of cave development on the coastal karst of Migjorn.

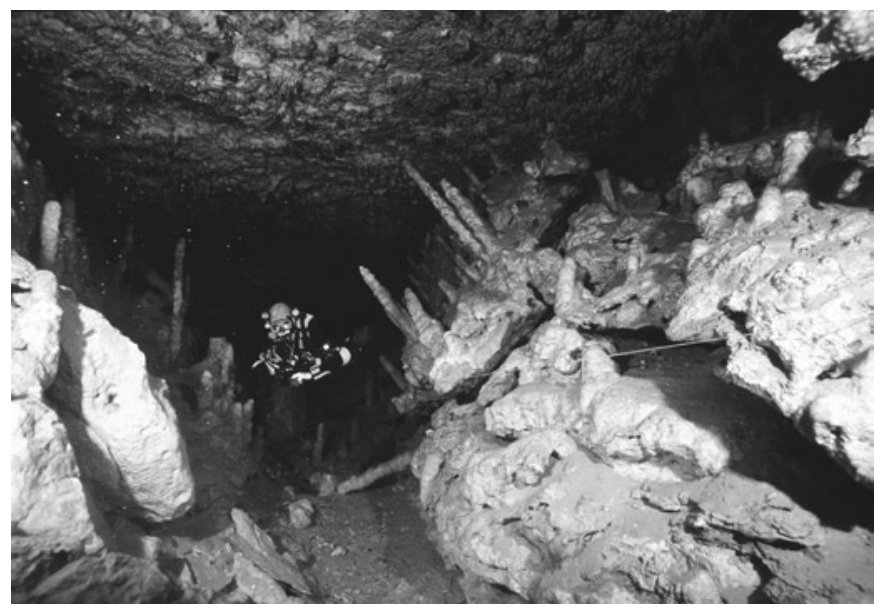

Fig. 6. Many underwater passages in the coastal caves of Migjorn are simply parts of wide breakdown chambers drowned due to the rise of the water table in Holocene times. Note the presence of collapse boulders and submerged rotated stalagmites in this sector of Cova Genovesa. 


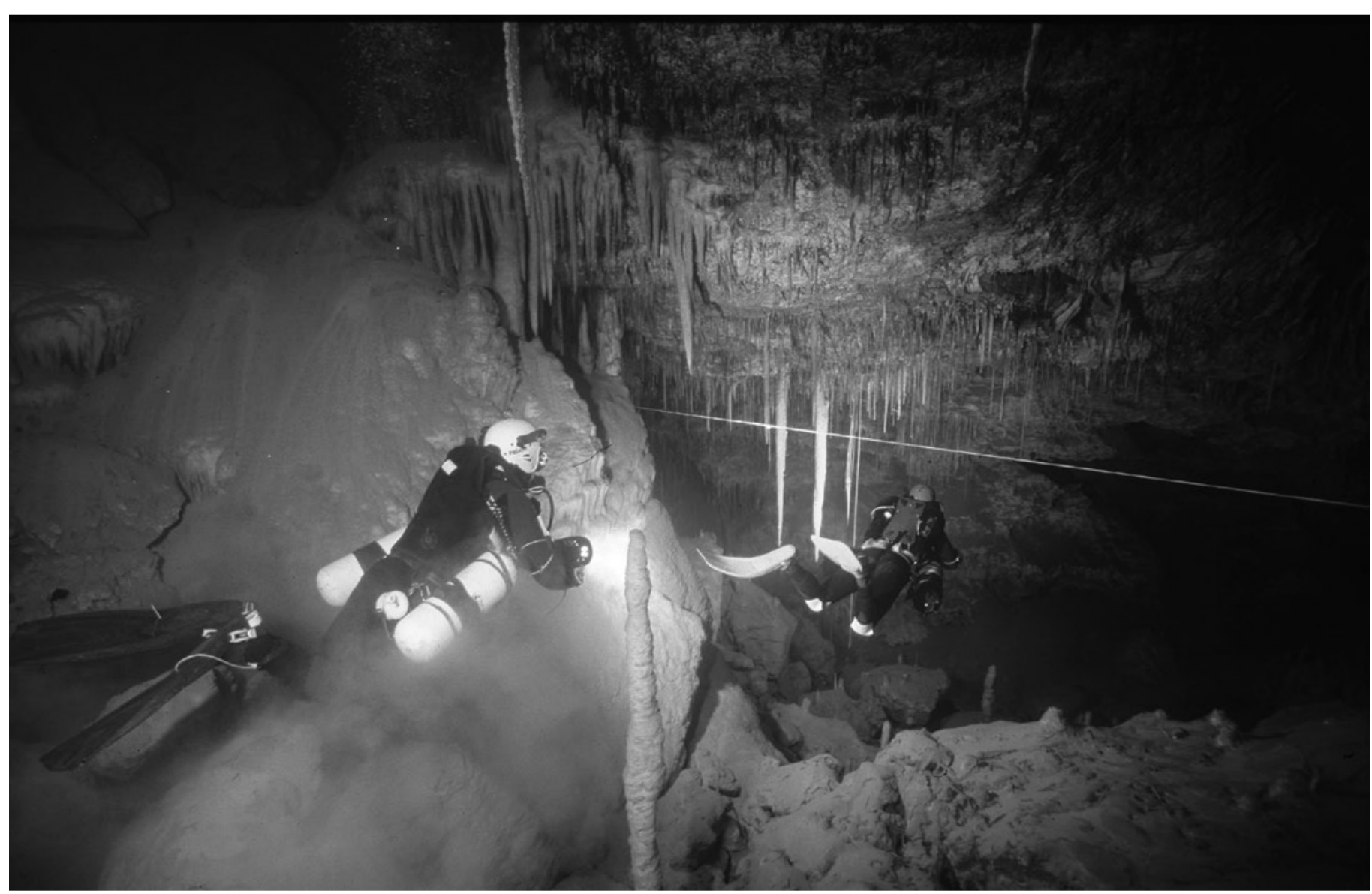

Fig. 7. A typical underwater landscape in Cova den Bassol. Scuba-diver exploration has substantially modified our knowledge of the coastal caves of Migjorn but the majority of the newly discovered areas -even if submerged-are not significantly different from the well decorated chambers of the celebrated Coves del Drac.

channels, tubes and diverse irregular passageways within a sea of interparticle porosity ... Fractures and caves, although locally present, are not a large part of the story". These assertions are supported to some extent by the observations made in the eogenetic karst of Mallorca. We also think that caves, even as extensive in surface and volume as Coves del Drac (Fig. 2), are not at all the main part of the story.

But then, what would explain the coexistence of such a "sea of porosity" (using the expression from Vacher $\&$ Mylroie, 2002) with such huge pores -the cavesthat cave divers have demonstrated to be connected to the sea? According to our hypothesis, the answer to this question may be: breakdown processes and sufficient time. Following subaerial exposure of young and porous limestones, subjected to eogenetic karst processes, the differences in original permeability between stratigraphic units may drive the water along preferential pathways, increasing the local porosity by diagenetic processes and generating secondary solution cavities, especially in the aggressive waters of the mixing zone. Evolution of intersecting vugs and pores and localized collapse can explain the beginning of the upward growth of many individual breakdown domes in areas of local stress and mechanical instability. In the current stage of development, collapse domes and vaults are widely present as the main speleogenetic unit that characterizes the vast majority of caves in the eogenetic karst of Migjorn (Ginés, 2000a \& 2000b). The importance of collapse in eogenetic caves has been also reported from southern Australia (Grimes et al., 1999), Yucatan (Smart et al., 2006) and Florida (Florea, 2006).

Overlapping terms such as eogenetic karst (Vacher \& Mylroie, 2002), syngenetic karst (Grimes, 2006) and "soft-rock" karst (Grimes, 2002), should be differentiated more clearly to avoid confusion. This has been partly addressed in a recent paper (White et al., 2007) which applies "syngenetic karst" as a broad term to all limestones that are still in the initial meteoric environment, i.e. within the eogenetic stage of diagenesis, and which have not been deeply buried. They divide syngenetic karst into syndepositional karst, which forms while deposition is continuing elsewhere within the same depositional sequence, and eogenetic karst which applies to subsequent karst within the syngenetic setting. Given that syndepositional karsts are rather uncommon, that unfortunately leaves syngenetic and eogenetic as overlapping terms for most karsts in youthful limestones. White et al. (2007) indicate that the duration of syngenetic and eogenetic karst is not limited in terms of absolute years, but by the duration of their diagenetic state.

"Soft-rock" karst is best kept as an informal descriptive term. Although the limestones hosting most syngenetic karsts are relatively soft and porous, some can be quite hard from the day of their creation, and some mesogenetic and telogenetic limestones can remain relatively soft. 


\section{SOME REMARKS ABOUT EOGENETIC CAVES}

The collapse chambers that characterize the endokarst developed on the Majorcan post-orogenic reef are closely related to recurrent rises and falls of the water table during the Quaternary. These complex cave systems were always controlled by sea level changes, as they are subjected to repeated phases of invasions and retreats of coastal phreatic waters. Every time the water table moved downwards, the loss of buoyant support increased the mechanical stress on the vaults and triggered local collapse. Every time the water table moved upwards, the vaults and boulder floors were drowned by mixtures of fresh and marine water, which caused further dissolution of limestone. Owing to these alternating events, the whole karst aquifer, including the developing cave systems, became adjusted to periods of stable and fluctuating water table and halocline at different (and sometimes recurrent) elevations. In this way, glacioeustatic sea-level fluctuations and related rises and falls of brackish pools in caves must be considered a major speleogenetic mechanism, provided that some additional processes can be envisioned to promote dissolution and removal of the rock.

The geochemistry of coastal-karst aquifers and of diagenetic processes from the water table to the halocline -and farther down- is far from well studied (Aquilina et al., 2005; Csoma et al., 2006). But, at the same time, there is general agreement that karstic voids can be generated in the freshwater-seawater mixing zone. The mixture of waters becomes undersaturated and is able to dissolve the rock and presumably form caves. On the basis of the pioneering studies in Yucatan by Back et al. (1979 \& 1984), the aggressive waters in the vicinity of the halocline are considered to be the main speleogenetical agent in coastal karsts, both eogenetic and telogenetic. Current research on coastal karst modelling emphasizes the role played by the mixing zone in the formation of caves (Mylroie \& Carew, 2000; Mylroie et al., 2004 \& Mylroie, 2005).

A problem arises in determining the exact mechanism for removal of the rock. Considering the great porosity of eogenetic karst, Vacher \& Mylroie (2002) suggest that "eogenetic caves of small carbonate islands are, for the most part, not significantly involved in the drainage of the island". On the basis of observations in the Migjorn karst of Mallorca, we also have the impression that many of its eogenetic caves are connected with each other and with seacoast springs (Fig. 3), but that they are not well integrated into an efficient drainage system (Fig. 2 and 8). Trying to find an explanation for the enormous amount of rock removed from caves as large as Coves del Drac or Cova de sa Gleda, we have focused our attention on tidal flushing. Periodic oscillations of the surface of glacioeustatic cave-pools are accompanied by significant movement of large masses of water through the more efficient submarine openings, namely caves. Perhaps tidal fluctuations affecting groundwaters near the shoreline, rather than conventional karstic flow, can account for the growth of many coastal caves in spite of the great secondary porosity and small hydraulic gradients typical of eogenetic karst. Thomas (1999) has reported substantial tidal flushing effects $2 \mathrm{~km}$ inland from the shoreline at Lifou island (Loyalty Archipelago) and more than $5 \mathrm{~km}$ in the coastal karsts of Yucatan and Cuba.

For the Majorcan eogenetic caves a likely hypothesis for speleogenetic stages could be as follows: 1) development of interconnecting vug systems in the mixing zone; 2) partial collapse of the most porous and unstable areas to generate breakdown domes; 3 ) recurrent rise and fall of the water table over long times (more than $1 \mathrm{Ma}$ ); 4) solutional removal of collapse debris in drowned caves favoured by tidal flushing; and 5) coalescing of collapsed areas to cause random connectivity between adjoining chambers. Finally, the propagation of breakdown domes towards the surface can give rise to cave entrances, while the connection between chambers can facilitate tidal movement of water through the more efficient pathways. Indirect evidence obtained by means of U-series datings on different types of speleothems suggests that the major speleogenetic events generating the caves of Migjorn are older than Middle Pleistocene. In fact, U-series datings obtained from phreatic overgrowths (Tuccimei et al., 2006), on speleothems located between 1.4 and 2.5 metres above current sea level, have demonstrated that since the Last Interglacial till the present the main chambers of these coastal caves were not affected by solutional processes nor substantially enlarged by collapse mechanisms.

\section{CONCLUSIONS ABOUT EOGENETIC SPELEOGENESIS}

Eogenetic caves in Mallorca are basically large collapse caverns. They are represented by many known caves and many kilometres of cave exploration and mapping (including some relevant underwater discoveries and accurate surveys). There are also several examples of what are presumably flank margin caves as well as other diverse types of caves, but they are the exception. The considerable amount of data supporting the prevalence of collapse caves in the eogenetic karst of Migjorn, seems difficult to reconcile with several statements that dominate in the literature on coastal speleogenesis, which almost ignore the role played by breakdown in the development of eogenetic caves. Only incidentally Mylroie \& Carew (1995) indicate that "on islands such as Bermuda,...vadose flow is channeled along the base of the limestone contact, which results in the lateral growth of vadose voids." They admit that "subsequent collapse of these voids, with continued dissolution of collapse debris, creates large chambers...". In the case of Mallorca, the Upper Miocene eogenetic karst overlies the Mesozoic rocks that belong to Serres de Llevant and, for this reason, some genetic relation between caves and localized discharge from underlying aquifers cannot be ruled out. But, even if cave origin could be promoted by recharge of water from neighbouring Mesozoic rocks along the base of the reefal unit, vadose flow is not a necessary condition to explain the evolution of these kinds of caves. 
Mylroie \& Carew (2000) describe different kinds of coastal caves that can be grouped in the following categories: pit caves, banana holes, flank margin caves, vadose contact caves, blue holes, and conduit caves. Vacher \& Mylroie (2002) enumerate the types of eogenetic caves as follows: small hollows and crevices associated with epikarst, banana holes, flank margin caves, vadose "stream caves", cavern systems associated with bank-margin fractures, and phreatic conduits. Mylroie (2005) focuses his explanation of coastal cave origin on sea caves, flank margin caves, and blue holes. Jenson et al. (2006) add three types of fissure cave and "phreatic lift" caves, but there is still little emphasis on collapse modification of the original cavities. Taking into account the increasing evidences about breakdown processes in coastal caves, we think that the Carbonate Island Karst Model as suggested by Mylroie et al. (2004) and Jenson et al. (2006) lacks a specific speleogenetic type based on long-lasting collapse of mixing-solution cavities, under the influence of recurrent sea level fluctuations and enhanced by "tidal pumping" on the coastal water table -as we are postulating for the Majorcan Migjorn caves.

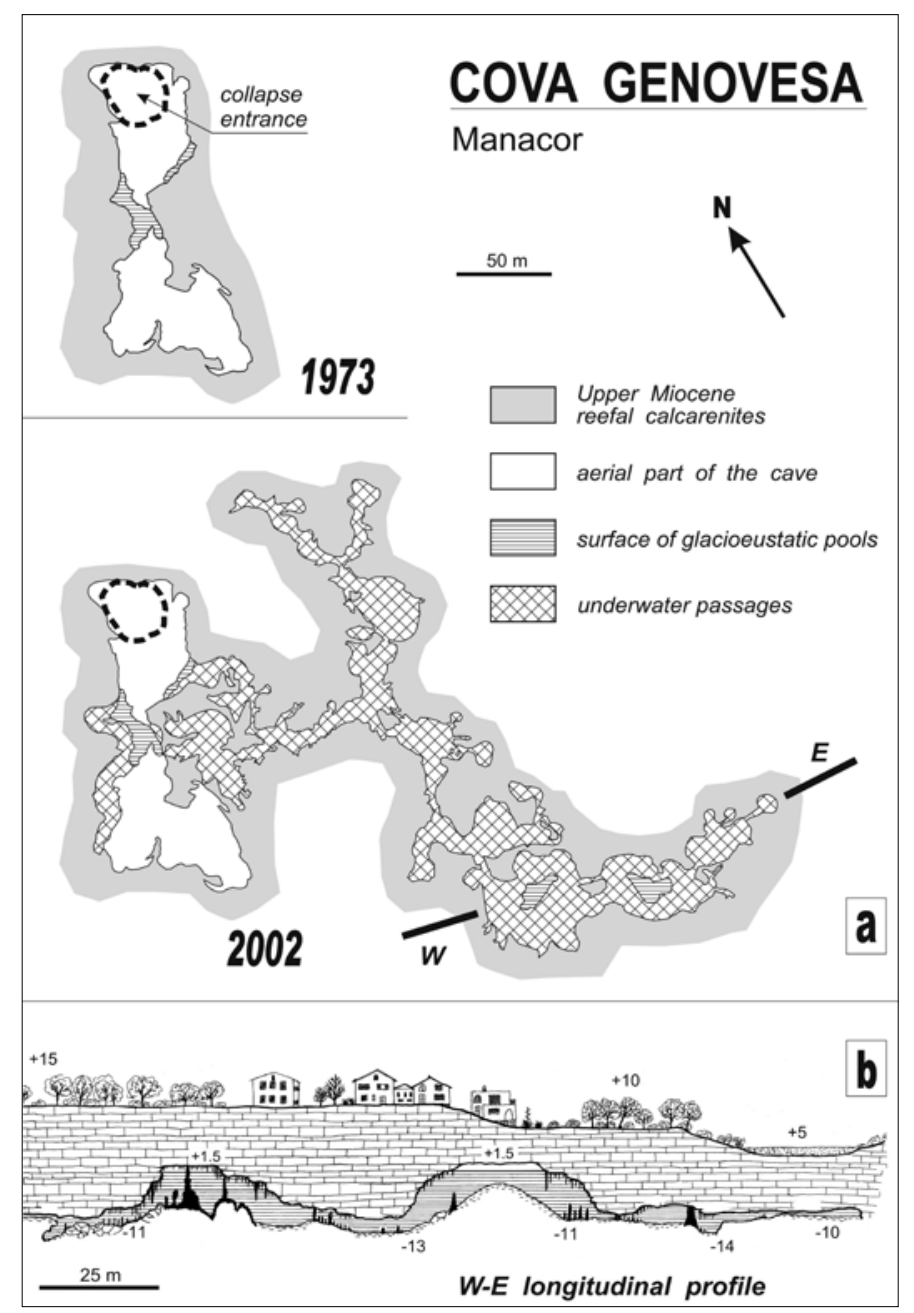

Fig. 8. Topographical survey from Cova Genovesa, after Gràcia et al. (2003). The comparison between the old and recent maps show the extent of the changes in the perception of the cave-patterns as have been reported by scuba-diver explorations. On the other hand, the underwater survey demonstrates that collapse chambers covered with speleothems are also common below the current water table.
Any discussion of eogenetic speleogenesis is necessarily conditioned by the geographic distribution of eogenetic karsts and by the unequal amounts of exploration and cave description for each locality. Any model of eogenetic speleogenesis must take into account the incomplete nature of our knowledge. Even for the well-known examples of eogenetic karst in the world, such as the Bahamas, Bermuda, or Yucatan, diving exploration can substantially modify our perception of the real pattern of the caves in only a few years. Our personal experience in the case of Mallorca is illustrative, especially when based on the excellent explorations and cave surveys carried out by Gràcia et al. (1997, 2000, 2003 \& 2005), which have radically modified our knowledge of the patterns of the submerged parts of several significant caves (Fig. 8). Furthermore, in addition to the useful data provided from several eogenetic karsts like Bahamas, Mona Island (Puerto Rico), Bermuda, and Guam, there are many different eogenetic karsts to include in the discussion. Some examples include Yucatan, Florida, Cuba, Christmas Island (Indian Ocean), Gambier and Nullarbor (southern Australia), Lifou island (Loyalty Archipelago), Puglia (southern Italy) and Mallorca. Finally, to make the model as general as possible, we suggest that the aim be shifted from a Carbonate Island Karst Model to an alternative and more useful Carbonate Coast Karst Model.

\section{ACKNOWLEDGEMENTS}

The authors would like to thank Art and Peggy Palmer for their suggestions and aid in the improvement of the former manuscript. Some clarifications about Neogene geology of Mallorca were kindly furnished by Joan Fornós. We are also grateful to Ken Grimes for his kindness and constructive criticism as well as to John Mylroie for his suggestions in order to ameliorate the paper. Francesc Gràcia, Oscar Espinasa and Pedro Gracia are thanked for the pictures and graphic material on underwater explorations kindly provided by them. This work was supported by the Research Project CGL2006-11242-C03-01 Ministerio de Educación y Ciencia - FEDER.

\section{REFERENCES}

Aquilina L., Emblanch C., Fidelibus M.D. \& Zuppi G.M., 2005 - Geochemical diagenesis of rock and groundwaters in karstic coastal aquifers. In: Tulipano L., Fidelibus M.D.\& Panagopoulos A. (Eds.) - Groundwater management of coastal karstic aquifers. Cost, European cooperation in the field of scientific and technical research:160-173.

Back W., Hanshaw J.N., Pyle L., Plummer L.N. \& Weidie A.E., 1979 - Geochemical significance of groundwater discharge and carbonate solution to the formation of Caleta Xel Ha, Quintana Roo, Mexico. Water Resources Research, 15 (6): 1521-1535.

Back W., Hanshaw B.B. \& Van Driel J.N., 1984 - Role of groundwater in shaping the eastern coastline of the Yucatan peninsula, Mexico. In: LaFleur R.G. (Ed.) - 
Groundwater as a geomorphic agent. Allen and Unwin: 281-293.

Balaguer P., 2005 - Tipus i evolució de les costes rocoses de Mallorca. Unpublished $\mathrm{Ph}$. D. Thesis, Universitat de les Illes Balears, Palma de Mallorca, 373 p.

Csoma A.É., Goldstein R.H. \& Pomar L., 2006 Pleistocene speleothems of Mallorca: implications for palaeoclimate and carbonate diagenesis in mixing zones. Sedimentology, 53: 213-236.

Choquette P.W. \& Pray L.C., 1970 - Geologic nomenclature and classification of porosity in sedimentary carbonates. American Association of Petroleum Geologists Bulletin, 54: 207-250.

Florea L.J., 2006 - Architecture of air-filled caves within the karst of the Brooksville Ridge, west-central Florida. Journal of Cave and Karst Studies, 68 (2): 64-75.

Fornós J.J., 1998 - Karst collapse phenomena in the Upper Miocene of Mallorca (Balearic Islands, Western Mediterranean). Acta Geologica Hungarica, 42 (2): 237-250.

Fornós J.J., Pomar L. \& Ramos E., 2002a - Tertiary: Balearic Islands. In: Gibbons W. \& Moreno T. (Eds.) - The Geology of Spain. Geological Society of London: 327-334.

Fornós J.J., Gelabert B., Ginés A., Ginés J., Tuccimei P. \& Vesica P., 2002b - Phreatic overgrowths on speleothems: a useful tool in structural geology in littoral karstic landscapes. The example of eastern Mallorca (Balearic Islands). Geodinamica Acta, 15: 113-125.

Gelabert B., 1998 - La estructura geológica de la mitad occidental de la Isla de Mallorca. Instituto Tecnológico Geominero de España, 129 p.

Gelabert B., Sàbat, F. \& Rodríguez-Perea A., 1992 - A structural outline of the Serra de Tramuntana of Mallorca (Balearic Islands). Tectonophysics, 203: 167-183.

Ginés A., 1997 - Edouard-Alfred Martel et la spéléologie à Majorque. In: André D. \& Duthu H. (Eds.) - L' homme qui voyageait pour les gouffres. Archives Départamentales de la Lozère: 291-300.

Ginés A., 2000a - Patterns of collapse chambers in the endokarst of Mallorca (Balearic Islands, Spain). Acta Carsologica, 29 (2): 139-148.

Ginés A. (Ed.), 2005 - Centenari de la troballa de Typhlocirolana moraguesi a les coves del Drac. Endins 28, special issue, Palma de Mallorca, 88 p.

Ginés A. \& Ginés J., 1977 - Datos bioespeleológicos obtenidos en las aguas cársticas de Mallorca. In: Vives S. et al. (Eds.) - Comunicacions бè Simposium d'Espeleologia. Centre Excursionista de Terrassa: 8195.

Ginés A. \& Ginés J., 1992 - Las Coves del Drac (Manacor, Mallorca). Apuntes históricos y espeleogenéticos. Endins, 17-18: 5-20.

Ginés A., Ginés J. \& Pomar L., 1981a - Phreatic speleothems in coastal caves of Mallorca (Spain) as indicators of Mediterranean Pleistocene paleolevels. In: Beck B.F. (Ed.) - Proceedings of the Eighth International Congress of Speleology. Georgia Southwestern College: 533-536.

Ginés J., 1995 - L' endocarst de Mallorca: els mecanismes espeleogenètics / Mallorca's endokarst: the speleogenetic mechanisms. Endins, 20: 71-86.
Ginés J., 2000b - El Karst litoral en el Levante de Mallorca: una aproximación al conocimiento de su morfogénesis $y$ cronología. Unpublished Ph. D. Thesis, Universitat de les Illes Balears, Palma de Mallorca, 595 p.

Ginés J., Ginés A. \& Pomar L., 1981b -Morphological and mineralogical features of phreatic speleothems occurring in coastal caves of Mallorca. In: Beck B.F. (Ed.) - Proceedings of the Eighth International Congress of Speleology. Georgia Southwestern College: 529-532.

Gràcia F., Watkinson P., Monserrat T., Clarke O. \& Landreth R., 1997 - Les coves de la zona de Ses Partions-Portocolom (Felanitx, Mallorca). Endins, 21: 536.

Gràcia F., Clamor B. \& Lavergne J.J., 2000 - Les coves de Cala Varques (Manacor, Mallorca). Endins, 23: 41-57.

Gràcia F., Jaume D., Ramis D., Fornós J.J., Bover P., Clamor B., Gual M.A. \& Vadell M., 2003 - Les coves de Cala Anguila (Manacor, Mallorca). II La Cova Genovesa o Cova d'en Bessó: espeleogènesi, geomorfologia, hidrologia, sedimentologia, fauna, paleontologia, arqueologia i conservació. Endins, 25: 43-86.

Gràcia F., Clamor B., Jaume D., Fornós J.J., Uriz M.J., Martín D., Gil J., Gracia P., Febrer M. \& Pons G., 2005 - La Cova des Coll (Felanitx, Mallorca): espeleogènesi, geomorfologia, hidrologia, sedimentologia, fauna $i$ conservació. Endins, 27: 141-186.

Grimes K.G., 2001 - Karst features of Christmas Island (Indian Ocean). Helictite, 37 (2): 41-58.

Grimes K.G., 2002 - Syngenetic and eogenetic karst: an Australian viewpoint. In: Gabrovsek F. (Ed.) - Evolution of Karst: from prekarst to cessation. Zalozba ZRC: 407-414.

Grimes K.G., 2006 - Syngenetic Karst in Australia: a review. Helictite, 39 (2): 27-38.

Grimes K.G., Mott K. \& White S., 1999 - The Gambier karst province. In: Henderson K. (Ed.) - Proceedings of the $13^{\text {th }}$ Australasian conference on cave and karst management. Australasian Cave and Karst Management Association: 1-7.

Holthuis L.B., 1973 - Caridean shrimps found in landlocked saltwater pools at four Indo-west Pacific localities (Sinai peninsula, Funafuti atoll, Maui and Hawaii islands), with the description of the new genus and four new species. Zoologische Verhandelingen, 128: 1-48.

Iliffe T.M., 2003 - Anchialine caves. In: Wilkens H., Humphreys W.F. \& Culver D.C. (Eds.) - Subterranean Ecosystems. Elsevier.

Jenson J.W., Keel T.M., Mylroie J.R., Mylroie J.E., Stafford K.W., Taboroši D. \& Wexel C., 2006 - Karst of the Mariana Islands: The interaction of tectonics, glacio-eustasy, and freshwater/seawater mixing in island carbonates. In: Harmon R.S \& Wicks C. (Eds.) - Perspectives on karst geomorphology, hydrology and geochemistry. Geological Society of America Special Paper 404: 129-138.

Merino A., Mulet A. \& Mulet G., 2006 - La Cova des Pas de Vallgornera : 23 kilómetros de desarrollo topografiado (Llucmajor, Mallorca). Endins, 30: 29-48.

Mylroie J.E., 2005 - Coastal Caves. In: Culver D.C. \& White W.B. (Eds.) - Encyclopedia of Caves. Elsevier Academic Press: 122-127. 
Mylroie J.E. \& Carew J.L., 1995 - Karst development on carbonate islands. In: Budd D.A., Saller A.H. \& Harris P.M. (Eds.) - Unconformities and porosity in carbonate strata. American Association of Petroleum Geologists: 55-76.

Mylroie J.E. \& Carew J.L., 2000 - Speleogenesis in coastal and oceanic settings. In: Klimchouk A.B., Ford D.C., Palmer A.N. \& Dreybrodt W. (Eds.) - Speleogenesis, evolution of karst aquifers. National Speleological Society: 226-233.

Mylroie J.E., Mylroie J.R. \& Jenson J.W., 2004 - Modeling carbonate island karst. In: Lewis R.D. \& Panuska B.C. (Eds.) - Proceedings of the $11^{\text {th }}$ Symposium on the geology of the Bahamas and other carbonate regions. Gerace Research Center: 135-144.

Palmer A.N., Palmer M.V. \& Queen J.M., 1977 - Geology and origin of the caves of Bermuda. In: Ford T.D. (Ed.) - Proceedings of the $7^{\text {th }}$ International Speleological Congress. British Cave Research Association: 336-339.

Pomar L. \& Ward W.C., 1999 - Reservoir-scale heterogeneity in depositional packages and diagenetic patterns on a reef-rimmed platform, Upper Miocene, Mallorca, Spain. AAPG Bulletin, 83 (11): 1759-1773.

Riedl R. \& Ozretic B., 1969 - Hydrobiology of marginal caves. Part I. General problems and introduction. Internationale Revue der Gesamten Hydrobiologie, 54 (5): 661-683.

Robledo-Ardila P.A., Durán J.J. \& Pomar L., 2004 - Paleocollapse structures as geological record for reconstruction of past karst processes during the Upper Miocene of Mallorca island. International Journal of Speleology, 33 (1/4): 81-94.

Rodés L., 1925 - Los cambios de nivel en las cuevas del Drach (Manacor, Mallorca) y su oscilación ritmica de 40 minutos. Memorias de la Academia de Ciencias y Artes de Barcelona, 19 (7): 207-221.

Sket B., 1996 - The ecology of the anchihaline caves. Trends in Ecology and Evolution, 11 (5): 221-225.
Sket B., 2004 - Anchialine habitats. In: Gunn J. (Ed.) - Encyclopedia of Caves and Karst Science. Fitzroy Dearborn: 64-66.

Sket B., 2005 - Anchialine caves. In: Culver D.C. \& White W.B. (Eds.) - Encyclopedia of Caves. Elsevier Academic Press: 30-37.

Smart P.L., Beddows P.A., Coke J., Doerr S., Smith S. \& Whitaker F.F., 2006 - Cave development on the Caribbean coast of the Yucatan Peninsula, Quintana Roo, Mexico. In: Harmon R.S \& Wicks C. (Eds.) Perspectives on karst geomorphology, hydrology and geochemistry. Geological Society of America Special Paper 404: 105-128.

Stock J.H., Iliffe T.M. \& Williams D., 1986 - The concept "anchialine" reconsidered. Stygologia, 2 (1-2): 90-92.

Taboroši D., 2004 - Caves and Karst of Guam. Bess Press, Honolulu, 105 p.

Tuccimei P., Ginés J., Delitala M.C., Ginés A., Gràcia F., Fornós J.J. \& Taddeucci A., 2006 - Last interglacial sea level changes in Mallorca island (Western Mediterranean). High precision U-series data from phreatic overgrowths on speleothems. Zeitschrift für Geomorphologie, 50 (1): 1-21.

Thomas C., 1999 - Aspects hydrogéologiques du Yucatan (Mexique). Karstologia, 34: 9-22.

Vacher H.L. \& Mylroie J.E., 2002 - Eogenetic Karst from the perspective of an equivalent porous medium. Carbonates and Evaporites, 17 (2): 182-196.

Vesica P.L., Tuccimei P., Turi B., Fornós J.J., Ginés A. \& Ginés J., 2000 - Late Pleistocene paleoclimates and sea-level change in the Mediterranean as inferred from stable isotope and U-series studies of overgrowth on speleothems, Mallorca, Spain. Quaternary Science Reviews, 19: 865-879.

White S.Q., Grimes K.G., Mylroie J.E. \& Mylroie J.R., 2007 - The earliest time of karst cave formation. Proceedings of the Time In Karst Conference. Karst Research Institute, Postojna: 1-5 (pdf on a CD). 